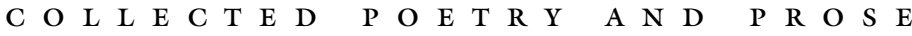





\title{
Dante Gabriel Rossetti
}

\section{Collected Poetry and Prose}

\author{
E D I T E D B Y J E R O M E M C G A N
}

Yale University Press / New Haven \& London 
Copyright (C) 2003 by Yale University. All rights reserved. This book may not be reproduced, in whole or in part, including illustrations, in any form (beyond that copying permitted by Sections 107 and I08 of the U.S. Copyright Law and except by reviewers for the public press), without written permission from the publishers.

Designed by Nancy Ovedovitz and set in Galliard Old Style type by Integrated Publishing Solutions, Grand Rapids, Michigan. Printed in the United States of America by Vail-Ballou Press, Binghamton, New York.

Library of Congress Cataloging-in-Publication Data Rossetti, Dante Gabriel, I828-I882.

[Selections. 2003]

Collected poetry and prose / Dante Gabriel Rossetti ; edited by Jerome McGann.

p. $\mathrm{cm}$.

Includes bibliographical references and indexes.

ISBN 0-300-0980I-4 (cloth : alk. paper)-ISBN 0-300-09802-2 (pbk. : alk. paper)

I. McGann, Jerome J. II. Title.

$\mathrm{PR}_{5242 . \mathrm{M}_{3} 82003}$

$82 \mathrm{I}^{\prime} .8-\mathrm{dc} 2 \mathrm{I} \quad 200219 \mathrm{IOI}$

A catalogue record for this book is available from the British Library.

The paper in this book meets the guidelines for permanence and durability of the Committee on Production Guidelines for Book Longevity of the Council on Library Resources.

IO $\quad 9 \begin{array}{lllllllll} & 9 & 7 & 6 & 5 & 4 & 3 & 2 & \text { I }\end{array}$ 